\title{
Low malathion concentrations influence metabolism in Chironomus sancticaroli (Diptera, Chironomidae) in acute and chronic toxicity tests
}

\author{
Débora Rebechi ${ }^{1}$, Vinicius S. Richardi ${ }^{1}$, Maiara Vicentini ${ }^{1}$, Izonete C. Guiloski ${ }^{2}$, \\ Helena C. Silva de Assis² \& Mário A. Navarro-Silva ${ }^{1,4}$
}

\begin{abstract}
${ }^{1}$ Laboratório de Entomologia Médica e Veterinária, Departamento de Zoologia, Universidade Federal do Paraná, Caixa Postal 19020, Curitiba, 81531-980-PR, Brazil. deborarebechi@hotmail.com; richardivs@gmail.com; maiaravicentini@gmail.com

${ }^{2}$ Laboratório de Toxicologia Ambiental, Departamento de Farmacologia, Universidade Federal do Paraná, Curitiba, Paraná, Brasil. guiloski@ig.com.br; helassis@ufpr.br

${ }^{4}$ Corresponding author: mnavarro@ufpr.br
\end{abstract}

\begin{abstract}
Low malathion concentrations influence metabolism in Chironomus sancticaroli (Diptera, Chironomidae) in acute and chronic toxicity tests. Organophosphate compounds are used in agro-systems, and in programs to control pathogen vectors. Because they are continuously applied, organophosphates often reach water sources and may have an impact on aquatic life. The effects of acute and chronic exposure to the organophosphate insecticide malathion on the midge Chironomus sancticaroli are evaluated. To that end, three biochemical biomarkers, acetylcholinesterase (AChE), alpha (EST- $\alpha$ ) and beta (EST- $\beta$ ) esterase were used. Acute bioassays with five concentrations of malathion, and chronic bioassays with two concentrations of malathion were carried out. In the acute exposure test, AChE, EST- $\alpha$ and EST- $\beta$ activities declined by 66,40 and $37 \%$, respectively, at 0.251 $\mu \mathrm{g} \mathrm{L}^{-1}$ and more than $80 \%$ at $1.37,1.96$ and $2.51 \mu \mathrm{g} \mathrm{L}^{-1}$. In chronic exposure tests, AChE and EST- $\alpha$ activities declined by 28 and $15 \%$ at $0.251 \mu \mathrm{g} \mathrm{L}^{-1}$. Results of the present study show that low concentrations of malathion can influence larval metabolism, indicating high toxicity for Chironomus sancticaroli and environmental risk associated with the use of organophosphates.
\end{abstract}

KEY WORDS. Acetylcholinesterase; bioindicator; esterases; organophosphate; toxicity.

Organophosphates are used worldwide to eliminate insect vectors of parasites and pathogens to humans and domestic animals, as well as to control agricultural pests. These compounds affect the central nervous system, causing spasms and death (Bartling et al. 2007). Malathion, an organophosphate insecticide, is highly toxic and has low specificity, which means that it affects a wide variety of organisms. From an ecological perspective, there is a concern about malathion's potential adversely affect non-target organisms, especially aquatic invertebrates (Xuereb et al. 2009).

Immature Chironomidae (Diptera) inhabit the benthic compartment of aquatic ecosystems (Di Veroli et al. 2012a; Lagauzère et al. 2009), and are important in the food chain dynamics as intermediates between producers and secondary consumers (Porinchu \& MacDonald 2003). Because they are sensitive to various pollutants (Preston 2002), reproduce easily and have short life cycles (Fonseca \& Rocha, 2004), chironomids are often used as indicators of acute and chronic toxicity in sediments and water contaminated with a variety of pollutants (eg. Al-Shami et al. 2010; Choung et al. 2013; Di Veroli et al. 2012b; Ebau et al. 2012; Jun et al. 2012; Roulier et al. 2008).

In aquatic ecosystems, the concentration of pollutants may not be high enough to cause mortality in animal communities. However, even in low concentration pollutants can cause damage to the entire ecosystem and its food chain. Consequently, sensitive markers should be used to assess the environmental health with respect to pollutants (Domingues et al. 2010). For this reason, the biomarker approach has be- come increasingly more popular. Its use is based on the assumption that low concentrations of toxic substances cause cellular responses in organisms before harmful effects can be observed in larger scales (Azevedo-Pereira et al. 2011; Domingues et al. 2010; Park et al. 2012).

Chironomus sancticaroli Strixino \& Strixino, 1981 is an endemic species from Brazil (long considered synonymous with Chironomus xanthus Rempel, 1939) (Trivinho-Strixino 2011) and has been used as a model in several studies (MoreiraSantos et al. 2005; Printes et al. 2011). The activities of enzymes that indicate neurotoxicity and detoxification are used in the midge, such as AChE (acetylcholinesterase) and GST (glutathione S-transferase), respectively.

The enzyme AChE is well-known and is used as a marker for exposure to organophosphates and carbamates (both inhibit this enzyme, resulting in a general nervous system failure (Fulton \& Key 2001)). GST, on the other hand, is a family of detoxifying enzymes that catalyze the combination of reduced glutathione (GSH) with a group of compounds having electrophilic centers (such as organophosphates and organochlorides). The products of this combination are usually less toxic and more soluble in water, hence are more easily excreted from cells (Crane et al. 2002). Increased activity of this enzyme is used as a marker of organic contamination (Domingues et al. 2010), even though its effects were not documented in some studies using Chironomidae (Callaghan et al. 2001; Crane et al. 2002; Rakotondravelo et al. 2006; Printes et al. 2011). 
Other biochemical markers can be used in studies on the effects of pesticides, for instance the metabolic enzymes alpha esterase and beta esterase, which bind to organophosphates and carbamates and slowly transform them (Hemingway \& Ranson 2000). The major objectives of the current study were to evaluate and compare the acute and chronic effects of malathion on immature $C$. sancticaroli by measuring the activity of the enzymes acetylcholinesterase, alpha and beta esterase that might indicate short- or long-term exposure.

\section{MATERIAL AND METHODS}

Midge larvae were obtained from a colony of the Laboratory of Medical and Veterinary Entomology, Federal University of Paraná (UFPR). This colony is maintained following the protocol of Maier et al. (1990), with modifications in the temperature $\left(25^{\circ} \mathrm{C} \pm 2\right)$ and photoperiod $(12 \mathrm{~h}$ light: $12 \mathrm{~h}$ dark). Voucher specimens of this colony are deposited in the Pe. Jesus Santiago Moure Entomological Collection of the Department of Zoology, UFPR (DZUP) with accession numbers from 249269 to 249276.

To estimate lethal concentrations of malathion for $C$. sancticaroli, bioassays were carried out in $300 \mathrm{ml}$ glass flasks. Each flask was provided with the following: $200 \mathrm{ml}$ test solution, $24 \mathrm{~g}$ sediment (sand composed of quartz and feldspar, granulometry $0.063-2.36 \mathrm{~mm},>50 \%$ of the sand grains were $\sim 1.18 \mathrm{~mm}$ ) and ten, 4th instar larvae. Four replicas of each nominal concentration of malathion $(0.3,0.9,1.5,2.1$, $2.7,3.3,3.9,4.5 \mu \mathrm{g} \mathrm{L}^{-1}$ ) and one control with $100 \%$ ethanol were used. Three bioassays were performed, each including 960 larvae (120 larvae per concentration). Bioassays lasted 96 hours and were kept in a BOD chamber at constant temperature $\left(25^{\circ} \mathrm{C} \pm 2^{\circ} \mathrm{C}\right)$ with a $12 \mathrm{~h}$ light $/ 12 \mathrm{~h}$ dark photoperiod. The lethal concentrations of the insecticide were estimated by Probit basic and linear regressions analyses. The no observed effect concentration (NOEC) is defined as the greatest concentration of a toxic substance that an organisms can be exposed to without showing adverse effects (USEPA 2000) and it was estimated by dividing the $\mathrm{LC}_{50}$ by ten.

Four replicas of each of the nominal concentrations of malathion $\left(0.1,0.251,1.37,1.96\right.$ and $\left.2.51 \mu \mathrm{g} \mathrm{L}^{-1}\right)$ and a control with ethanol $100 \%$ were used for the acute toxicity bioassays (96h). The first concentration selected represented the value established by Resolution 357 of the National Environmental Council (CONAMA) on March 17, 2005, as the Class 1 freshwater limit (water for human consumption after simple treatment) in Brazil. It was chosen to determine whether this concentration is harmless to $C$. sancticaroli. The other four concentrations were based on previous calibration with this species and included the NOEC and values estimated from the following lethal concentrations: 10, 30 and $50\left(\mathrm{LC}_{10}, \mathrm{LC}_{30}\right.$ and $\left.\mathrm{LC}_{50}\right)$. The chronic toxicity tests (6 days) were carried out in glass aquaria $(30 \mathrm{~cm} \times 20 \mathrm{~cm} \times 10$ $\mathrm{cm}$ ). All aquaria contained $375 \mathrm{~g}$ sediment (as described above), constant aeration and a final solution volume of $3 \mathrm{~L}$. Every two days $0.2 \mathrm{~g}$ TetraMin ${ }^{\circledR}$ food was added and the solution test was renewed weekly. Larval exposure began at the egg stage with the two lowest sub-lethal concentrations of malathion $\left(0.1\right.$ and $\left.0.251 \mu \mathrm{g} \mathrm{L}^{-1}\right)$, and the control with ethanol $100 \%$ in four replicas. The bioassays were carried out in a BOD chamber with constant temperature $\left(25 \pm 2^{\circ} \mathrm{C}\right)$ and photoperiod of $12 \mathrm{~h}$ light/ $12 \mathrm{~h}$ dark. Each enzyme activity was measured with 50 larvae per concentration, with a total of 900 larvae acutely exposed and 450 larvae chronically exposed.

Larvae of acute and chronic toxicity bioassays were stored in a freezer at $-80^{\circ} \mathrm{C}$ and were subsequently homogenized in $300 \mu \mathrm{l} 0.1 \mathrm{M} \mathrm{pH} 7.5$ potassium phosphate buffer (for the enzyme AChE) and in $150 \mu 10.2 \mathrm{M} \mathrm{pH} 7.2$ potassium phosphate buffer (for the enzymes EST- $\alpha$ and EST- $\beta$ ), followed by centrifugation at $12,000 \mathrm{x}$ g for 1 minute at $4^{\circ} \mathrm{C}$.

For the enzyme AChE we followed Ellman et al. (1961) modified for microplates following Silva de Assis (1998). The EST- $\alpha$ and EST- $\beta$ activities followed the methodology by Valle et al. (2006). Total protein per larva was measured following Bradford's (1976) protocol. The biochemical analyses were carried out on a BioTek microplate reader.

Statistical analyses were carried out in the program R ( R Development Core Team 2011). A generalized linear model (GLM) was adjusted through a Gamma error distribution using MASS libraries (Venables and Ripley 2002) and effects (Fox 2003). Given that the data met the assumptions of independence, normality, and homoscedasticity, One-way ANOVA and Tukey contrasts $(\mathrm{p} \leqslant 0.05)$ were used for a posteriori comparissions using a multcomp library (Hothorn et al. 2008).

\section{RESULTS}

Malathion concentrations ranging from 0.95 to $7.51 \mu \mathrm{g}$ $\mathrm{L}^{-1}$ were lethal to Chironomus sancticaroli. Based on this lethal range, we selected concentrations to expose the organisms for biomarker evaluation. The lethal concentration 50 $\left(\mathrm{LC}_{50}\right)$ was $2.51 \mu \mathrm{g} \mathrm{L}^{-1}$, from which we obtained the value of the no observed effect concentration (NOEC) of $0.25 \mu \mathrm{g} \mathrm{L}^{-1}$ (Table I).

Table I. Lethal concentrations of the malathion compound for Chironomus sancticaroli expressed in $\mu \mathrm{g} \mathrm{L}^{-1}$ and confidence interval (CI).

\begin{tabular}{ccc}
\hline Lethal concentrations & Concentrations $\left(\mu \mathrm{g} . \mathrm{L}^{-1}\right)$ & $\mathrm{CI}\left(\mu \mathrm{g} . \mathrm{L}^{-1}\right)$ \\
\hline LC2 & 0.95 & $0.81-1.08$ \\
LC 10 & 1.37 & $1.22-1.51$ \\
LC 30 & 1.96 & $1.81-2.09$ \\
LC 50 & 2.51 & $2.36-2.65$ \\
LC 70 & 3.21 & $3.03-3.42$ \\
LC 90 & 4.59 & $4.24-5.05$ \\
LC 99 & 7.51 & $6.62-8.82$ \\
\hline
\end{tabular}

In order to understand the effects caused by short- and longterm exposure to malathion we exposed $C$. sancticaroli to two nominal concentrations $\left(0.1\right.$ and $\left.0.25 \mu \mathrm{g} \mathrm{L}^{-1}\right)$, both acutely and chronically. At the concentration $0.1 \mu \mathrm{g} \mathrm{\textrm {L } ^ { - 1 }}$ (the maxi- 
mum allowed by Brazilian legislation), no mortality occurred among 4th instar larvae exposed for a brief interval (96h). Nonetheless, this exposure still led to a significant decrease in the activity of the enzymes AChE and EST- $\beta$ (46 and 25\%, respectively, Fig. 1A). When exposure was continuous, beginning with the egg stage, this insecticide concentration caused a reduction in enzymatic activity (AChE, EST- $\alpha$ and EST- $\beta$ decreased 15,8 and 5\%, respectively) which was not significantly different from the control (Fig. 1B).

Mortality did not occur when the organisms were exposed to acute toxicity bioassays at $0.25 \mu \mathrm{g} \mathrm{L}^{-1}$ (NOEC), but enzyme activities significantly decreased $(66,40$ and $37 \%$ for AChE, EST- $\alpha$ and EST- $\beta$, respectively, Fig. 1A). When organisms were chronically exposed to the same concentration, enzymatic activity declined again for AChE and EST- $\alpha$ by 28 and $15 \%$, respectively (Fig. 1B).

A concentration-dependent relationship was found in the present study for the three enzymes (Fig. 1A and Table II). After the sub-lethal concentration $\mathrm{LC}_{10}\left(1.37 \mu \mathrm{g} \mathrm{L}^{-1}\right)$, some mortality occurred (Table II) and enzyme activity of the three enzymes decreased more than $78 \%$ in survivors.
Table II. Percent inhibition of the enzymes AChE, EST- $\alpha$ and EST- $\beta$ and the mortality observed in Chironomus sancticaroli exposed to five concentrations of malathion. There was no mortality in the control.

\begin{tabular}{|c|c|c|c|c|c|c|c|}
\hline \multirow{3}{*}{$\begin{array}{l}\text { Concentration } \\
\left(\mu \mathrm{g} . \mathrm{L}^{-1}\right)\end{array}$} & \multicolumn{6}{|c|}{ Inibition (\%) } & \multirow{3}{*}{$\frac{\text { Acute }}{\text { Mortality (\%) }}$} \\
\hline & \multicolumn{3}{|c|}{ Acute } & \multicolumn{3}{|c|}{ Chronic } & \\
\hline & $\mathrm{AChE}$ & $\mathrm{EST}-\alpha$ & EST- $\beta$ & AChE & EST- $\alpha$ & EST- $\beta$ & \\
\hline 0.10 & $47^{a}$ & 17 & $25^{\mathrm{a}}$ & 15 & 08 & 0.5 & 0 \\
\hline 0.25 & $67^{\mathrm{a}}$ & $41^{\mathrm{a}}$ & $37^{\mathrm{a}}$ & $28^{\mathrm{a}}$ & $16^{\mathrm{a}}$ & 0.6 & 0 \\
\hline 1.37 & $97^{\mathrm{a}}$ & $86^{\mathrm{a}}$ & $80^{\mathrm{a}}$ & & & & 41 \\
\hline 1.96 & $98^{\mathrm{a}}$ & $89^{\mathrm{a}}$ & $82^{\mathrm{a}}$ & & & & 62 \\
\hline 2.51 & $98^{\mathrm{a}}$ & $91^{\mathrm{a}}$ & $78^{\mathrm{a}}$ & & & & 77 \\
\hline
\end{tabular}

${ }^{\mathrm{a}}$ Indicates $\mathrm{p}<0.05$ (using one-way ANOVA and Tukey).

\section{DISCUSSION}

Neurotoxicity and metabolic detoxification caused by pesticides are often detected with the help of marker enzymes. In the present study, the activity of three marker enzymes was impacted by malathion, even in the concentrations permitted by the Brazilian law.

Inhibition of the activity of the three marker enzymes used in this study, even when the concentrations of malathion
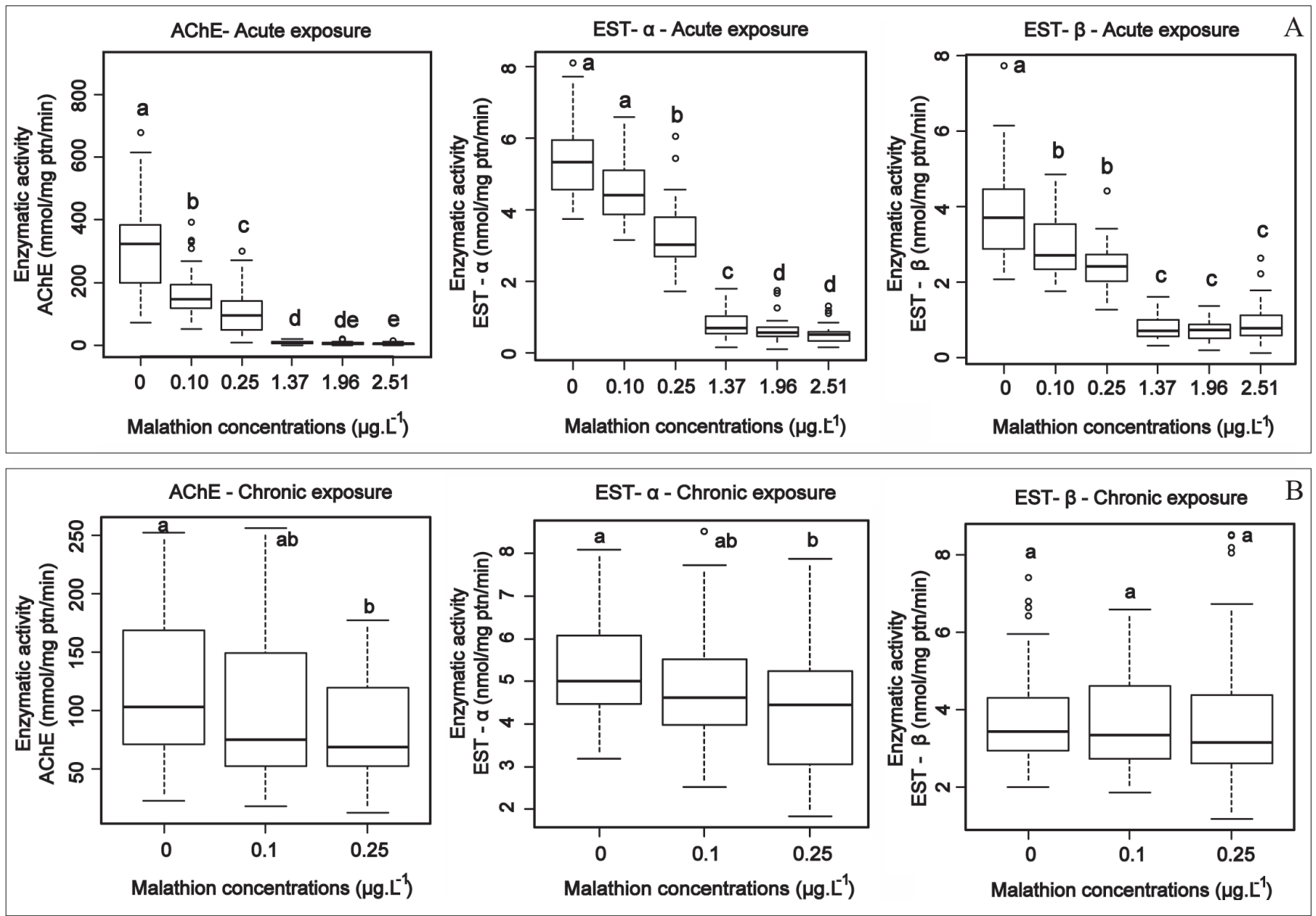

Fig. 1. Concentrations of the insecticide malathion compared with a control through enzymatic activity of the enzymes acetylcholinesterase (AChE); alpha esterase (EST- $\alpha)$ and beta esterase (EST- $\beta$ ) in Chironomus sancticaroli. A: Acute toxicity $(96 \mathrm{~h})$ of five concentrations. B: Chronic toxicity of two concentrations. The values express the average enzymatic activity \pm upper and lower quartiles $(\mathrm{n}=50$ for each group). Different letters indicate significant differences for $\mathrm{p}<0.05$ (using one-way ANOVA and Tukey contrasts). 
are very low, may affect the metabolism and thus the fitness of organisms. Rakondravelo et al. (2006), studying the effects of exposing Chironomus tentans Fabricius, 1805 for 20 days to concentrations of $0.1 \mu \mathrm{g} \mathrm{L}^{-1}$ of the organophosphate insecticide chlorpyrifos, reported that the activity of the following enzymes (percentage of inhibition in parenthesis) was inhibited: AChE (60\%), EST- $\alpha$ (31\%), and EST- $\beta$ (49\%). In our work we also detected enzymatic inhibition, though in a smaller scale, which is consistent with previous tests that found chlorpyrifos to be more harmful to Chironomidae than malathion (Stevens 1992).

As expected, the no observed effect concentration (NOEC) did not result in mortality. However, enzymatic alterations were detected. A similar outcome was achieved by Beyers \& Sikoski (1994), who obtained a $24 \%$ inhibition of the AChE activity after exposing the fish Ptychocheilus lucius Girard, 1856 to the NOEC calculated for the species. Jin-Clark et al. (2008) exposed Chironomus tentans to a concentration of $0.25 \mu \mathrm{g} \mathrm{L}^{-1}$ of the organophosphate insecticide chlorpyrifos, obtaining 70\% inhibition of the AChE. According to Day \& Scott (1990) a $50 \%$ inhibition of the AChE generally affects the survival of organisms. Even though vulnerability differs among individuals, our results indicate that our C. sancticaroli study population may have been affected.

According to Buchwalter et al. (2004), different larval instars of the same species differ in their vulnerability to xenobiotics. Usually, younger larvae are more vulnerable than older ones. Therefore, it is expected that chronic exposure to low concentrations of xenobiotics would lead to stronger enzymatic inhibition when compared to acute exposure to the same substance in the same concentration (Rakotondravelo et al. 2006). However, our results do not indicate that. Greater enzymatic inhibition resulted after acute exposure to malathion in the concentrations of 0.1 and $0.25 \mu \mathrm{g} . \mathrm{L}^{-1}$, when compared to chronic exposure. This may be due to the biochemical detoxification mechanism of our subjects, which partially recover after the initial exposure phase. This detoxification mechanism ensures survival at least when concentrations of the insecticide are low (Hemingway and Karunaratne 1998).

Several studies have confirmed a direct relationship between xenobiotic concentrations and enzyme inhibition (Callaghan et al. 2001; Forcella et al. 2007; Mehler et al. 2008; Printes et al. 2007). Such concentration-dependent relationship was found in this study for the three enzymes analyzed. Esterases, which eliminate organophosphates from the body using hydrolysis or sequestration of compounds, are considered the main enzymes in the detoxification of these compounds. Therefore, inhibition of these enzymes can minimize the effects of the insecticide on the AChE, providing greater chances of survival for individuals (Rakondravelo et al. 2006).

The significant reduction in AChE activity (Table II) reveals that larvae are able to survive inhibition of this enzyme, at least for short periods. Similar results were found by Domingues et al. (2007), who reported that larvae of Chironomus riparius Meigen, 1804 exposed to the organophosphate dimethoate remained alive after $66 \%$ inhibition of the AChE. Berra et al. (2006) observed that Hydropsyche pellucidula Curtis, 1834 (Trichoptera, Hydropsychidae) is able to survive the phenitrothion even after $97 \%$ enzymatic activity inhibition.

Although larvae do survive high levels of enzyme inhibition, a behavioral effect observed in organisms exposed to organophosphate compounds is limited mobility or paralysis, which is attributed to inhibition of the AChE. The latter is responsible for proper nervous system functioning (Azevedo-Pereira et al. 2011). Paralysis, which was mainly observed in organisms exposed to higher concentration of malathion, can have serious ecological consequences. Paralyzed larvae have difficulties feeding and are unable to protect themselves in the substrate using their silk pipe constructions, becoming more susceptible to predation and to being carried away by the water currents, affecting population density (Callaghan et al. 2001).

In micro-quantities, malathion can be considered toxic to $C$. sancticaroli and impact populations of this species, also disrupting the food chain. Furthermore, malathion residues found in aquatic environments affect the entire aquatic community and, consequently, humans. Studies have reported that malathion is associated with Parkinson's disease, neurocognitive disorders in children, and is capable of triggering a metabolic predisposition to weight gain (Holtcamp 2012; Moretto \& Colosio 2013).

In conclusion, our study shows that the insecticide malathion in very toxic to the midge $C$. sancticaroli, after short- and long-term exposure. A continual release of this compound, even at the sub-lethal concentrations accepted by the Brazilian legislation, can influence the metabolism of the midge, with consequences to individual behavior, growth and survival. The entire food web may be also influenced by the effects of malathion on larvae of this midge.

\section{ACKNOWLEDGEMENTS}

We thank Conselho Nacional de Desenvolvimento Científico e Tecnológico (CNPq), grant number 305038/2009-5.

\section{REFERENCES}

Al-Shami, S. A., Rawi, C.S.M., Ahmad, A.H. \& Nor, S.A.M. 2010. Distribution of Chironomidae (Insecta: Diptera) in polluted rivers of the Juru River Basin, Penang, Malaysia. Journal of Environmental Sciences 22: 1718-1727.

Azevedo-Pereira, H.M.V.S., Lemos, M.F.L. \& Soares, A.M.V.M. 2011. Effects of imidacloprid exposure on Chironomus riparius Meigen larvae: linking acetylcholinesterase activity to behaviour. Ecotoxicology and Environmental Safety 74: 1210-1215.

Bartling, A., Worek, F., Szinicz, L. \& Thiermann, H. 2007. Enzyme-kinetic investigation of different sarin analogues reacting with human acetylcholinesterase and butyrylcholinesterase. Toxicology 233: 166-172.

Berra, E., Forcella, M., Giacchini, R., Rossaro, B. \& Parenti, P. 2006. Biomarkers in caddisfly larvae of the species Hydropsyche pellucidula (Curtis, 1834) (Trichoptera: Hydropsychidae) measured in natural populations and after short term exposure to fenitrothion. Bulletin of Environmental Contamination and Toxicology 76: 863-870. 
Beyers, D.W. \& Sikoski, P.J. 1994. Acetylcholinesterase inhibition in federally endangered colorado squawfish exposed to carbaryl and malathion. Environmental Toxicology and Chemistry 13: 935-939.

Bradford, M. 1976. A rapid and sensitive method for the quantification of microgram quantities of protein utilizing the principle of protein-dye binding. Analytical Biochemistry 72: 248-254.

Buchwalter, D.B., Sandahl, J.F., Jenkins, J.J. \& Curtis, L.R. 2004. Roles of uptake, biotransformation, and target site sensitivity in determining the differential toxicity of chlorpyrifos to second to fourth instar Chironomous riparius (Meigen). Aquatic Toxicology 66: 149-157.

Callaghan, A., Hirthe, G., Fisher, T. \& Crane, M. 2001. Effect of short-term exposure to chlorpyrifos on developmental parameters and biochemical biomarkers in Chironomus riparius Meigen. Ecotoxicology and Environmental Safety 50: 19-24.

Choung, C.B., Hyne, R. V, Stevens, M.M. \& Hose, G.C. 2013. The ecological effects of a herbicide-insecticide mixture on an experimental freshwater ecosystem. Environmental Pollution 172: 264-274.

Crane, M., Sildanchandra, W., Kheir, R. \& Callaghan, A. 2002. Relationship between biomarker activity and developmental endpoints in Chironomus riparius Meigen exposed to an organophosphate insecticide. Ecotoxicology and Environmental Safety 53: 361-369.

Day, K. \& Scott, I. 1990. Use of acetylcholinesterase activity to detect sublethal toxicity in stream invertebrates exposed to low concentrations of organophosphate insecticides. Aquatic Toxicology 18: 101-114

Di Veroli, A., Goretti, E., Paumen, M.L., Kraak, M.H.S. \& Admiraal, W. 2012a. Induction of mouthpart deformities in chironomid larvae exposed to contaminated sediments. Environmental Pollution 166: 212-217.

Di Veroli, A., Selvaggi, R. \& Goretti, E. 2012b. Chironomid mouthpart deformities as indicator of environmental quality: a case study in Lake Trasimeno (Italy). Journal of Environmental Monitoring 14: 1473-1478.

Domingues, I., Agra, A.R., Monaghan, K., Soares, A. M.V. M. \& Nogueira, A.J.A. 2010. Cholinesterase and Glutathione-S-Transferase activities in freshwater invertebrates as biomarkers to assess pesticide contamination. Environmental Toxicology and Chemistry 29: 5-18.

Domingues, I., Guilhermino, L., Soares, A. M.V. M. \& Nogueira, A.J.A. 2007. Assessing dimethoate contamination in temperate and tropical climates: potential use of biomarkers in bioassays with two chironomid species. Chemosphere 69: 145-154.

Ebau, W., Rawi, C.S.M., Din, Z. \& Al-Shami, S. A. 2012. Toxicity of cadmium and lead on tropical midge larvae, Chironomus kiiensis Tokunaga and Chironomus javanus Kieffer (Diptera: Chironomidae). Asian Pacific Journal of Tropical Biomedicine 2: 631-634

Ellman, G.L., Courtney, K.D., Andres, V.J. \& Featherstone, R.M. 1961. A new and rapid colorimetric determination of acetylcholinesterase activity. Biochemical Pharmacology 7: 88-95.

Fonseca, A. L. \& Rocha, O. 2004. Laboratory cultures of the native species Chironomus xanthus Rempel, 1939 (Diptera, Chironomidae). Acta Limnologica Brasiliensia 16: 153-161.

Forcella, M., Berra, E., Giacchini, R., Rossaro, B., \& Parenti, P. 2007. Increased alanine concentration is associated with exposure to fenitrothion but not carbamates in Chironomus riparius larvae. Ecotoxicology and Environmental Safety 66: 326-334.

Fox, J. 2003. Effect displays in R for generalised linear models. Journal of Statistical Software 8: 1-27.

Fulton, M.H. \& Key, P.B. 2001. Acetylcholinesterase inhibition in estuarine fish and invertebrates as an indicator of organophosphorus insecticide exposure and effects. Environmental Toxicology and Chemistry 20: $37-45$.

Hemingway, J. \& Karunaratne, S.H.P.P. 1998. Mosquito carboxylesterases: a review of the molecular biology and biochemistry of a major insecticide resistance mechanism. Medical and Veterinary Entomology 12: 1-12.

Hemingway, J. \& Ranson, H. 2000. Inseticide resistance in insect vectors of human disease. Annual Review of Entomology 45: 371-391.

Holtcamp, W. 2012. Obesogens: an environmental link to obesity. Environmental Health Perspectives 120: a62-a68.
Hothorn, T., Bretz, F. \& Westfall, P. 2008. Simultaneous inference in general parametric models. Biometrical Journal 50: 346-363.

Jin-Clark, Y., Anderson, T.D. \& Zhu, K.Y. 2008. Effect of alachlor and metolachlor on toxicity of chlorpyrifos and major detoxification enzymes in the aquatic midge, Chironomus tentans (Diptera: Chironomidae). Archives of Environmental Contamination and Toxicology 54: 645-652.

Jun, Y.-C., Won, D.-H., Lee, S.-H., Kong, D.-S. \& Hwang, S.-J. 2012. A multimetric benthic macroinvertebrate index for the assessment of stream biotic integrity in Korea. International Journal of Environmental Research and Public Health 9: 3599-3628.

Lagauzère, S., Pischedda, L., Cuny, P., Gilbert, F., Stora, G. \& Bonzom, J.-M. 2009. Influence of Chironomus riparius (Diptera, Chironomidae) and Tubifex tubifex (Annelida, Oligochaeta) on oxygen uptake by sediments. Consequences of uranium contamination. Environmental Pollution 157: 1234-1242.

Maier, K.J., Kosalwat, P. \& Knight, A.W. 1990. Culture of Chironomus decorus (Diptera: Chironomidae) and the effect of temperature on its life history. Environmental Entomology 19: 1681-1688.

Mehler, W.T., Schuler, L.J. \& Lydy, M.J. 2008. Examining the joint toxicity of chlorpyrifos and atrazine in the aquatic species: Lepomis macrochirus, Pimephales promelas and Chironomus tentans. Environmental Pollution 152: 217-224.

Moreira-Santos, M., Fonseca, A.L, Moreira, S.M., Rendón-von Osten, J., Silva, E.M., Soares, Amadeu, M. V. M., Guilhermino, L. \& Ribeiro, R. 2005. Short-term sublethal (sediment and aquatic roots of floating macrophytes) assays with a tropical chironomid based on postexposure feeding and biomarkers. Environmental Toxicology and Chemistry 24: 2234-2242.

Moretto, A., \& Colosio, C. 2013. The role of pesticide exposure in the genesis of Parkinson's disease: epidemiological studies and experimental data. Toxicology 307: 24-34.

National Environmental Council - CONAMA 357/05 - Resolution CONAMA 357 March 17, 2005. Environmental Ministry. Available at: http:/www.mma.gov.br. (accessed 30 March 2012).

Park, S.-Y., Nair, P.M.G. \& Choi, J. 2012. Characterization and expression of superoxide dismutase genes in Chironomus riparius (Diptera, Chironomidae) larvae as a potential biomarker of ecotoxicity. Comparative Biochemistry and Physiology Part C 156: 187-194.

Porinchu, D.F. \& MacDonald, G.M. 2003. The use and application of freshwater midges (Chironomidae: Insecta: Diptera) in geographical research. Progress in Physical Geography 27: 378-422.

Preston, B.L. 2002. Indirect effects in aquatic ecotoxicology: implications for ecological risk assessment. Environmental Management 29: 311323 .

Printes, L.B., Espíndola, E.L.G., \& Fernandes, M.N. 2007. Biochemical biomarkers in individual larvae of Chironomus xanthus (Rempel, 1939) (Diptera, Chironomidae). Journal of the Brazilian Society of Ecotoxicology 2: 53-60.

Printes, L.B., Fernandes, M.N. \& Espíndola, E.L.G. 2011. Laboratory measurements of biomarkers and individual performances in Chironomus xanthus to evaluate pesticide contamination of sediments in a river of southeastern Brazil. Ecotoxicology and Environmental Safety 74: 424-430.

R Development Core Team 2011. R: A language and environment for statistical computing. Vienna, R Foundation for Statistical Computing,. Available at: http://www.R-project.org. (accessed 17 April 2013).

Rakotondravelo, M.L., Anderson, T.D., Charlton, R.E. \& Zhu, K.Y. 2006. Sublethal effects of three pesticides on activities of selected target and detoxification enzymes in the aquatic midge, Chironomus tentans (Diptera: Chironomidae). Archives of Environmental Contamination and Toxicology 51: 360-366.

Roulier, J.L., Tusseau-Vuillemin, M.H., Coquery, M., Geffard, O. \& Garric, J. 2008. Measurement of dynamic mobilization of trace metals in sediments using DGT and comparison with bioaccumulation in Chironomus riparius: first results of an experimental study. Chemosphere 70: 925-932. 
Silva de Assis, H.C. 1998. Der Einsatz von Biomarkern zur summarischen Erfassung von Gewässerverschmutzungen. Ph.D. Thesis. Technische Universität Berlin, 83 p.

Stevens, M.M. 1992. Toxicity of organophosphorus insecticides to 4thinstar larvae of Chironomus tepperi Skuse (Diptera, Chironomidae). Journal of the Australian Entomological Society 31: 335-337.

Trivinho-Strixino, S. 2011. Chironomidae (Insecta, Diptera, Nematocera) do estado de São Paulo, sudeste do Brasil. Biota Neotropica 11: 675-684.

US Environmental Protection Agency (USEPA). 2000. Methods for measuring the toxicity and bioaccumulation of sediment-associated contaminants with freshwater invertebrates. EPA 600/R-99/064. Wa- shington, DC.

Valle, D., Montella, I.R., Ribeiro, R.A., Medeiros, P.F.V., Martins-Jr, A.J. \& Lima, J.B.P. 2006. Quantification methodology for enzyme activity related to insecticide resistance in Aedes aegypti. Série A. Normas e Manuais Técnicos. Rio de Janeiro, Fundação Oswaldo Cruz and Secretaria de Vigilância em Saúde, Ministério da Saúde, 128 p.

Venables, W.N. \& Ripley, B.D. 2002. Modern Applied Statistics with SPlus, 4th ed. New York, Springer, xi+495 p.

Xuereb, B., Lefèvre, E., Garric, J. \& Geffard, O. 2009. Acetylcholinesterase activity in Gammarus fossarum (Crustacea Amphipoda): linking AChE inhibition and behavioural alteration. Aquatic Toxicology 94: 114-122.

Received 12 February 2014; accepted 12 June 2014

Associate Editor: Maria Anice M. Sallum 